\title{
THE EUROPEAN UTOPIA IN ZWEIG'S BRAZIL. A LAND OF THE FUTURE
}

\author{
David Fontanals \\ ADHUC, Universitat de Barcelona
}

Aвsтract: The publication in i94I of Stefan Zweig's Brazil. A Land of the Future (Brasilien. Ein Land der Zukunft) was met both with great enthusiasm and harsh criticisms. Many reviewers thought that Zweig's view of the country was too exotic, naive, idealistic, utopian, and even the result of the propaganda efforts carried out by the Vargas administration. In an attempt to understand and bridge the gap between Zweig's idea of Brazil and the country's «reality», this article analyzes the text hand in hand with Zweig's memoirs and other of his non-fiction works from the perspective of his utopian thinking and ethical commitment to the notions of freedom, peace, cosmopolitanism, tolerance, and common understanding. Keywords: Stefan Zweig; ethical commitment; Europe; utopia; Brasilien. Ein Land der Zukunft.

A utopia europeia em O Brasil: país do Futuro de Zweig

Resumo: A publicação em i94I de Brazil, um país do futuro (Brasilien. Ein Land der Zukunft), de Stefan Zweig, foi recebida com um grande entusiasmo e com as críticas mais duras. Muitos críticos pensaram que a visão que Zweig tinha do país era exótica, ingênua, idealista e utópica demais, refletindo até o resultado dos esforços de propaganda realizados pelo governo Vargas. Na tentativa de compreender e preencher o vazio entre a ideia que Zweig tinha do Brasil e a «realidade» do país, este artigo analisa o texto junto com as memórias de Zweig e outros trabalhos de não-ficção a partir da perspetiva do seu pensamento utópico e do compromisso ético das noções de liberdade, paz, cosmopolitismo, tolerância e entendimento comum.

Palavras-chave: Stefan Zweig; compromiso ético; Europa; utopia; Brasilien. Ein Land der Zukunft.

\section{Between the World of Yesterday AND the LAND of the Future: LOCATING ZWEIG'S EUROPEAN UTOPIA}

Stefan Zweig's memoirs The World of Yesterday (Die Welt von Gestern) —written in I94I and published posthumously in 1942 by the Swedish Bermann-Fis-

Fontanals, David (2019). «The European Utopia in Zweig's Brazil. A Land of the Future». Abriu, 8, 179-195. ISSN: 2014-8526. e-ISSN: 2014-8534. DOI: 10.1344/abriuzor9.8.10. Received: 30/8/2018. Accepted: $28 / 1 / 2019$. 
cher Verlag - do not only encapsulate the life experiences of the Austrian writer and intellectual, together with an account of Europe's history from the fin-de-siècle to the beginning of the Second World War, but they also function as the ultimate legacy of its author in terms of his commitment to an idea of the world (Weltanschaunng) and an ethical project that, although it had been defeated by violence and war, could still be reenacted by future generations (Zweig 2009: 2I-22). In this sense, the act of writing down one's life acquires an existential turn that goes hand in hand with the condition of exile (Evelein 20I4). Ostracized and forcefully separated from his homeland(s) (Austria and Europe), his language and readership, as well as from his dream of a supranational European community based on freedom, peace, cosmopolitanism, tolerance, common understanding, and pluralism, Zweig could not see light beyond. In his suicide note (Declaração), he wrote: «But after one's sixtieth birthday unusual powers are needed in order to make another wholly new beginning. Those that I possess have been exhausted by years of homeless wandering. [...] I salute all my friends! May it be granted them to see the dawn after the long night! I, all too impatient, go on before» (in Prater 1972: 339).

We could argue that a sense of impending doom - the pervading sense of living (at) the end of a world - forced Zweig to locate his utopia in the past, the only place that felt safe at the time and which could be «relived» and «(re) imagined» from memory. More specifically, he used an adulterated and sugarcoated version of the golden age of his youth in fin-de-siècle Vienna — what he calls in the first chapter of his memoirs «the age of security»— to build the basis for his ideal community. Consequently, the most superficial and literal readings tend to criticize the work for being nostalgic, naive, idealistic, ahistorical and, above all, lacking the political commitment that could be expected from an exiled Jewish writer in times of war and persecution (see, for instance, Arendt 2004 and Marquis 1978). However, a second reading of the text can be defended, one that does not take Zweig's descriptions at face value, but which reads into the blanks and silences of his work —as well as into the process of stylization and narrativization of the text - to reconstruct his ethical commitment, which, in turn, becomes a guide to reread, analyze, and navigate the rest of his work. This alternative reading entails a redefinition of certain key concepts often used against Zweig. On the one hand, we must not think of utopia as a necessarily idealistic stance, but as potential space for articulating one's commitment (Levitas 2013). Also, on the other hand, there is more to nostalgia than the longing for a past that no longer exists or an uncritical approach to history 
that entails the abdication of personal responsibility. Instead, in Zweig, as in other writers, nostalgia becomes the crossroads of past and future, a way of looking at history for unrealized potentialities (Boym 200I).

Having said that, we must bear in mind that, in the last years of his exile, Zweig looked for other places, besides fin-de-siècle Vienna, to locate both his ethical commitment and his utopia. While Europe, engaged in a suicidal war, did not offer many possibilities or future hopes, South America, and especially Brazil, were something else. From his very first visit to the country in 1936, Zweig was enthralled by the beauty and potentialities of the land, and so in a way he started projecting all his hopes and dreams onto this, for him, «new found land». The result of this fascination was to be one of his last and most polemic works, Brazil. A Land of the Future (Brasilien. Ein Land der Zukunft), published in I94I simultaneously in four languages (Portuguese, French, German and English). As we will see later, it was met both with the highest praise and the harshest of criticisms, either as a tribute to Brazil from one of the most prominent European authors of the time or as a work of propaganda financed by the government of the dictator Getúlio Vargas. Coincidentally enough, most judgements resemble those of The World of Yesterday, dubbing the work as a too idealistic, picturesque, exotic, and utopic description of an otherwise poverty-ridden and totalitarian state. While that is a legitimate claim, it is also true, as it was for Zweig's autobiography, that the author never intended to write either a factual and accurate history of Europe or a comprehensive view of Brazil. On the contrary, Zweig's idealism, which had earned him so many reproaches and condemnations, was based on the belief in the power of ideas and art to transcend both time and space. For Zweig, at a time of failure and estrangement, in the mental framework of the apocalypse, both fin-de-siècle Vienna and Brazil became places to ensure that his ethical commitment survived an all too scary and destructive present (see Hu 2006: 92). From this perspective, we could argue that Brazil is a sort of afterthought to Zweig's memoirs, an epilogue that opens up a new space to unleash the potentialities of his commitment. Taking all this into account, this article attempts a non-literal reading of the text from the perspective of Zweig's ethical project and utopian thinking, ${ }^{1}$ analyzing it

- Alberto Dines, in his biography of Zweig Morte no paraiso (I98I), was one of the first to propose a utopian reading of Zweig's text. Others who have followed this line of inquiry are Schwamborn (1999: 67-104; 137-143); Kestler (1992: 175-179); Pooth (2005); Dewulf, (2014: 137-I46); Weidong (2015: 229-236). 
together with his autobiography and in the context of his intellectual engagement as writer.

\section{STEFAN ZWEIG IN BRAZIL}

Before analyzing the way in which Zweig's European utopia unfolds in his work Brazil. A Land of the Future, it is important to lay out its genesis and context of production, since they will provide us with some key information to understand the composition of the text as well as some aspects of its reception. Zweig visited Brazil on three different occasions. The first visit occurred during Zweig's first South American tour, which took place from the $8^{\text {th }}$ August to the $6^{\text {th }}$ October 1936. Zweig had been invited to participate in the International PEN Congress in Buenos Aires (from the $4^{\text {th }}$ to the $14^{\text {th }}$ September). However, upon the insistence of his Brazilian publisher Abrahao Koogan and following a formal invitation of the Brazilian government, Zweig decided to make a stop off in Brazil first, where he arrived on the $2 \mathrm{I}^{\text {st }}$ August 1936. According to Oliver Matuschek, his fame and success in both Europe and Brazil ensured him «a reception worthy of an official state visitor» (20II: 293). A tightly packed schedule took him from Rio de Janeiro to Petrópolis, Sao Paulo and Santos, including a visit to a coffee plantation and several other activities which were later incorporated in his first account of Brazil, Kleine Reise nach Brasilien ( $\mathrm{A}$ Short Trip to Brazil»), a series of articles published in the Hungarian journal Pester Lloyd in 1936. In these first impressions, we can already observe a fascination with the land, especially with the beauty of Rio, which was to become the core experience of Zweig's idea of Brazil. At the end of the journey, Zweig asked Abrahao Koogan not to publish these articles, since he had in mind to visit the country again the following year and then write a whole book about his journey. Both the second trip and the book would have to wait a few years due to both historical and personal circumstances - the Spanish Civil War in 1936, the Anschluss in Austria in 1938, and Zweig's divorce from his first wife Friderike, among other things- - Finally, in 1940, Zweig went back to Brazil to complete his research for the book, which was published in November 194I. ${ }^{2}$ By then,

${ }^{2}$ The book remained out of print until Zweig's Iooth $^{\text {th }}$ anniversary in I98I, when, according to Volker Michels (20I2), it had even greater success. 
Zweig had obtained a permanent visa $\left(5^{\text {th }}\right.$ November 1940) and rented a house in Petrópolis for six months ( $17^{\text {th }}$ September $\left.194 \mathrm{I}\right)$, where he lived with his second wife Lotte until they committed suicide on the $22^{\text {nd }}$ February 1942.

\section{Brazil as the Promised Land in Stefan ZWeig's Brazil. A LAND OF THE FUTURE}

The contents of Brazil. A Land of the Future are divided into two very different parts. The first comprises the «Introduction» and the chapters «History», «Economy» and «A Look at Brazilian Culture», and is used by Zweig to develop his idea of Brazil, whereas the second is dedicated to narrating a journey — or tour — around some of Brazil's most prominent sights. We could contend that, whereas the first is an essay on several aspects of the country, the second resembles a sort of travel book, partly derived from the articles written in 1936 (Matuschek 20II: 334). Following the book's order, we will start by carrying out a close reading of the «Introduction», which offers us some key ideas for unravelling the not-so-obvious layers of the text.

\section{1. «The Idea of Brazil»: Redefining Western Civilization}

The first thing that must be noted is that Zweig establishes in the prologue a direct link between his text and the well-known accounts by the «discoverers» of America in the $15^{\text {th }}$ and $16^{\text {th }}$ centuries (Dines $198 \mathrm{I}$ ): «Today Brazil is still as much terra incognita in the cultural sense as it was to the first seafarers in the geographical sense» (Zweig 2000: 5). Thus, he acknowledges the fact that the way he looks at Brazil is tinted by his European mindset, by a sort of prefiguration and anticipation that make his account deviate to a certain extent from «reality». Once he has cast off the European arrogance that expects Brazil to be «one of the South American republics among which nobody makes precise distinctions, with a hot, unhealthy climate, with turbulent political conditions and desolate finances [...] but with beautiful scenery and unutilized possibilities», he knows that he has «gazed into the future of our world» (Zweig 2000: 5). However, at his point, after embracing the beauty and possibilities of the land, he also runs the risk, as did the first Crónicas de Indias, of getting carried away and embellishing or distorting reality. We must not forget that, as we said at 
the beginning, Zweig was desperate, running away from the «European insanity of nationalism and racism» (Zweig 2000: 10), wishing «to escape for a time from a world that was destroying itself, into one that was peacefully and creatively building» (Zweig 2000: 7). Hence it is from this very specific mindset, which establishes a connection between the old and the new continent, between Zweig's memoirs and Brazil, that we must read his enthusiasm and his willingness to project and materialize his European «failed» utopia.

Moreover, Zweig sets a very specific goal for the text: aware of the impossibility of conveying a complete general picture of the country, he chooses to focus on one single issue: How Brazil, despite all its differences and contrasts, has managed to coexist peacefully and harmoniously. For, according to Zweig, no other country has been able to find a most exemplary answer to the question «How can human beings achieve a peaceful coexistence on earth, in spite of all the disparate races, classes, colors, religions, and convictions?» (Zweig 2000: 9). From this moment onwards, Brazil becomes Europe's dialogical opposite, acquiring all the traits and ideals that are no longer realizable in the old continent. For instance, nationalism, which in Europe has turned every country against its neighbors and therefore has become, according to Zweig's memoirs, «the ultimate pestilence that has poisoned the flower of our European culture» (Zweig 2000: 20), here in Brazil has managed to unite a community made up of the most diverse elements, fomenting a national culture defined by the notions of harmony, equality, intermixing, softness (in opposition to vehemence), tolerance, and peace.

Above all, according to Zweig, the «idea of Brazil» defies the basis of any racial theory by proving that «the constant intermingling and reciprocal adaptation under the same climate and living conditions has developed a thoroughly unique type that completely lacks all the "corrupting" traits that have been blusteringly announced by the racial purity fanatics» (Zweig 2000: II). Finally, all this has deeper consequences for a European who, by witnessing that another way of living together is possible —as the humanists and pacifists had imagined for Europe in the interwar period-, is forced to redefine the standard of civilization: «I am no longer willing to equate them [civilization and culture] unhesitatingly with the concepts of organization and comfort. [...] I am no longer willing to recognize a hierarchy based on the industrial, the financial, the military striking power of a nation, but am rather inclined to determine the measure of a country's exemplariness based on its peaceful nature and its humane attitude» (Zweig 2000: I4). 


\subsection{Freedom, Tolerance and Peace: the Historical Roots of Zweig's Brazilian Utopia}

All these arguments, notions, and ideas developed by Zweig in the introduction — and which make Brazil «a land of the future» — form the core of his ethical program as articulated both in his memoirs and in a significant number of his texts. In fact, most of these concepts recur throughout Brazil, informing Zweig's vision of the country's history, economy and culture. The first thing that must be said is that it is no surprise that Zweig starts by looking at Brazil's past. In an autobiographical sketch published in 1936, the Austrian writer emphasized the importance of the study of history in his attempt to understand the present: «With the coming of the war [...], I began a new study of it [History], so that I might better understand our present time; and in particular the periods of critical uprisings in the past gave analogies of the present» (Schreiber 1936: 175). What is more, Zweig defends a very particular historiography, one which instead of dealing with the military achievements of the nation should show «how to accomplish universal movement, progress, civilization. The history of tomorrow must be a history of all humanity» (Zweig 2016: I70). In this sense, the most salient aspects of Zweig's history of Brazil will be those that have contributed to the development of the «idea of Brazil» and therefore to the moral betterment of humankind.

On the one hand, amid a number a basic facts and dates, Zweig highlights the role of the Jesuit missionaries in bringing to the country the ideas of civilization, the intermixing of races (mestiçagem), freedom and peace. Whereas other colonizers are there only for immediate profit, the Jesuits are the first whose aim «is directed into the future, into a span of centuries, yes, into eternity, [which] sets them so magnificently in contrast with the bureaucracy and military forces who want quick and visible profits for themselves and their homeland» (Zweig 2000: 30). Equally, according to Zweig, they started to carry out through education «the idea of systematic mixing that formed Brazil into a whole, and which alone preserved it as an integrated unit» (Zweig 2000: 30). Finally, Zweig traces back to the action of the Jesuit missionaries the notions of freedom and equality: «According to their plan the future Brazil shall not consist of a master nation of whites and a slave nation of colored people, but only of a unified free people on free soil» (Zweig 2000: 36). It must be noted here that the idea of freedom was one of Zweig's lifelong obsessions, to the point that his first wife Friderike defined him in her memoirs as «the freest of 
persons, a fanatic of liberty» (F. Zweig 2008: 153). Consequently, following the humanist trail of Cicero, Erasmus and Castellio, Zweig wrote a very short portrait of Michel de Montaigne, a figure that embodies for Zweig the ideal of the citoyen du monde, a cosmopolitan identity that cannot be realized without freedom. From Zweig's perspective, Montaigne symbolizes individual freedom, a kindred spirit in the fight against tyranny: «Only he whose soul is in turmoil, forced to live in an epoch where war, violence and ideological tyranny threaten the life of every individual, and the most precious substance in that life, the freedom of the soul, can know how much courage, sincerity and resolve are required to remain faithful to his inner self in these times of the herd's rampancy» (Zweig 2015: 269-27I).

On the other hand, and following the same line of discussion, the next protagonists are the Dutch colonizers and, more specifically, their leader Moritz von Nassau. They were responsible for continuing and expanding the civilizing mission of the Jesuits. Not only did they bring an entire army of scholars, scientists, engineers, etc., but they also fomented the ideals of tolerance and pacifism. As for the former - tolerance- being closely associated with the credo of humanism, it is one of the most relevant aspects of zweigian ethics. In his own words, «Moritz von Nassau cuts a good figure in Brazilian history. As a humanist he has brought the idea of tolerance with him, permitted all religions to work freely, made possible fruitful development in all the arts, and even the old settlers cannot complain about any violence» (Zweig 2000: 49). Inevitably, this discussion of humanism and tolerance, as happened with freedom and Montaigne, opens a new layer of intertextuality within Zweig's works that takes us, for instance, to his biography Erasmus (1934). This text —a sort of veiled (self)portrait that strives between engagement and evasion in the face of the rise of Hitler and totalitarianism in Europe (Jouhaud 2009) — defends the figure of the artist as a mediator and the intellectual as the guardian of inner freedom. A position that seeks to unite individuals and peoples beyond any frontier, fostering the ideal of universal understanding and excluding intolerance. In this sense, Erasmus's «greatest asset was that he was endowed with a forbearing disposition which enabled him to exercise the rare art of minimizing conflicts by indulgent understanding, of clearing up ambiguities, of smoothing out confusions, of reuniting what had been rent, of giving back a mutual cohesion to those who were divided» (Zweig I979: 4).

Finally, Zweig develops in this chapter the idea that, also historically, the Brazilian rarely resorts to violence, for essentially «the Brazilian is neither rad- 
ical nor revolutionary» (Zweig 2000: 57). Even the abdication of Pedro I «happily preserves the Brazilian tradition that national political takeovers be accomplished if possible without the shedding of blood and in a conciliatory manner. Quietly, not pursued by hatred and resentment, the first emperor of Brazil leaves the country» (Zweig 2000: 64). Among all the great political and military figures of Brazilian history, Zweig praises the figure of Pedro II, who in his eyes embodies the ideal of the humanist and scholar: «Pedro II is by nature a contemplative individual, more a private scholar or librarian who landed on the throne than a man of politics or the army» (Zweig 2000: 65). Thus, pacifism — a philosophy which Zweig had embraced since the First World War under the guidance of one his masters, the French Nobel Prize winner Romain Rolland - is, in the end, one of the deepest traits of Brazilian identity both at the individual and collective levels: «In all its different forms Brazil has not changed in the deepest sense; [...] it has applied the same method in both its internal and its external politics: peaceful resolution of all conflicts through mutual conciliation» (Zweig 2000: 70).

\subsection{Mestiçagem, Cordiality and... Eurocentrism?}

The chapter dedicated to Brazil's economy — where Zweig does not seem to find much room to project his utopia- focuses on explaining the several economic cycles of Brazil in order to understand not only its deficiencies but also, above all, to emphasize its enormous potential (Zweig 2000: 74). Additionally, it also deals with the various migratory movements, both within the country and from abroad, that have contributed to its diversity. And here we must make a short deviation to point out one of the negative byproducts of Zweig's fixation with the idea of Europe. If we claim that the articulation of Zweig's ethical program is one of the keys not only to make sense of his legacy but also to include his works in our discussions on ethics, Europe, postnationalism, or the role of literature and the artist's commitment, among others, we must also establish the limits of Zweig's thinking. Can we say that, by exporting or projecting his European utopia onto Brazil, Zweig's discourse in his memoirs - those of a European according to the text's subtitle- becomes automatically universal? Although that may be the author's intention, the truth is that the text is underpinned to a large extent by Eurocentrism, primitivism and even, to some extent, racism. Without going any further, on the topic of migration, 
Zweig writes that «this immigration of from four to five million white people during the last fifty years has been an enormous injection of energy for Brazil [...]. The Brazilian race, which threatened to grow darker, more and more African in skin color, as a result of importing Negroes for three hundred years, grows visibly lighter in color again, and the European element, unlike the primitively developed, illiterate slaves, raises the general level of civilization» (Zweig 2000: I09-II0). What I contend, following the ideas of the literary critic José Heredia Maya as recently discussed by the Americanist Rodrigo Andrés, is that we are obliged, when discussing or teaching Zweig's or, in fact, anyone else's works, to highlight those instances where the author may promote any sort of discrimination or hate, whenever he implements what Heredia terms the «mirada sucia» («contaminated gaze»), a biased and prejudiced way of looking at the other (Andrés 2018: iı)).

Going back to Zweig's text, this first part of the work ends with an assessment of Brazilian culture, including a discussion of the country's character, lifestyle and artistic achievements. Here Zweig deals once again with many of the traits mentioned in the introduction, namely harmony, conciliatoriness, intermixing, pacifism, softness, etc. After asserting - in the most Eurocentric fashion - that «nothing that we now call Brazilian and recognize as such can be explained on the basis of a Brazilian tradition, but only on that of a creative transformation of something European by the land, the climate and its people» (Zweig 2000: 124), Zweig focuses on the idea of softness or lack of vehemence. In other words, Zweig thinks that the Brazilian is by nature non-violent, to the point of justifying murder as a sudden fit of passion: «The Brazilian is instinctively repelled by anything brutal, and it has been statistically determined that murder and mayhem almost never occur as planned and premediated acts, but always spontaneously as crimes of passion, as sudden outbreaks of jealousy or wounded pride» (Zweig 2000: 127). It must be said that, for Zweig, this idea of softness, non-vehemence, or even silence, is imbued with an ethical sense. In fact, as George Prochnik argues (20I4: 127), there is a direct association in Zweig's thought between demagoguery and noisemaking in contrast with the quiet forces of reason. As opposed to Hitler's discourses that emphasized hardness and physical strength, «Zweig believed that silent withdrawal could render a form of moral judgement, and that such stereotypically female attributes as softness, receptivity [...] could serve an ethical purpose» (Prochnik 20I4: I29).

Next to the ideas of courtesy, goodness, harmony and delicacy, which have already been discussed, Zweig reflects again on the ideal of civilization 
materialized in Brazil. As we observed in the first section of this article, the vision of Brazilian society made Zweig rethink the notions of «culture» and «civilization». At this point in the text, he insists on the fact the Brazilian places a higher value on pleasure than economic ambition, offering an alternative to the idea of progress as it is conceived in Europe and North America, and discussing «whether or not something in the human spiritual domain dries up and withers away in this attempt to extract a hundred percent of a human being's dynamic power» (Zweig 2000: I34). All in all, «the commercial statistics, the dry numbers of the balance of trade, are confronted here with invisible benefits: undisturbed, unmaimed humanity and peaceful contentment» (Zweig 2000: 134). Summing up, Zweig offers an image of Brazil as a socially and racially harmonious community based on the principles of peaceful coexistence and intermixing. However, even though we posit that all these ideas and values stem from Zweig's utopian thinking and ethical stance, he was not the only one who promoted these principles. In fact, his definition of Brazil's character engages directly with the debates on Brazilian identity that took place in the decades following the end of the First World War.

According to Horst Nitschak (20I4), the Great War ended with the West's hegemony as a model of progress, resulting in a Brazilian modernist movement that drew on the country's own history to develop an autochthonous discourse apart from colonization, European superiority, racism and social rigidity. In this process of construction of a collective identity, two notions must be highlighted in connection with Zweig's Brazil. On the one hand, the sociologist Gilberto Freyre develops in Casa Grande \& Senzala the notion of intermixing or mestiçagem understood not as a form of biological discrimination, but as an ethnical and cultural strength. On the other hand, Sérgio Buarque de Holanda's concept of cordialidade encapsulates a way for individuals to relate to one another away from institutions, establishing the basis for negotiating difference and coexisting peacefully. Although it is difficult to determine the extent to which these theories influenced Zweig's vision of the country, we know for certain that he did some research before writing the book and it is likely that he read or was told about these authors and their ideas on Brazilian identity (Dewulf 20I4). 3 However, as we have said before, these notions can be found in

3 It must be noted here that, although Zweig was not alone in reading the concept of «cordialidade» as a trait of Brazilian pacifism, Sérgio Buarque de Holanda himself provided 
some of Zweig's works predating his visits to Brazil and, therefore, we can only speculate as to their influence on Zweig's ethical program and point out the fact that they form one of the text's intertextual layers, adding arguments to an already fertile soil for the articulation of Zweig's utopia.

\subsection{From Vienna to Rio}

Following this line of discussion, we come to the second part of the text, where Zweig takes us on a tour of the country's most prominent cities and landmarks. With the impressionistic, affirmative, and hyperbolic style that characterizes his travel writings (see Zweig 2010), this second part fulfills the function of giving a spatial and corporeal reality to the community Zweig has analyzed and described in the first part of the text, showing the reader how some of his impressions of Brazil emanated from a physical experience of discovery and beauty. Will Stone, in the preface to a selection of Zweig's travel essays, envisages a similar function for Zweig's European journeys, that of «stitch[ing] the uncooperative continent together» (Stone 20II: Xv). Thus, traveling and community-building go hand in hand. Additionally, in this part of the text, we also find one of the core experiences that defines Zweig's vision of Brazil, namely his visit to Rio. In his description of the city, Zweig projects his idealized image of fin-de-siècle Vienna as it is delivered in the conference «The Vienna of Yesterday» («Die Wien von Gestern», April I940) or more famously in the first chapter of The World of Yesterday. In fact, this projection of Vienna starts in the section dedicated to Brazilian culture, where Zweig assigns to Brazil some of the traits for which the Austro-Hungarian capital was known among the European elite of the turn of the century: the existence of an «aristocracy of the spirit» represented by some of the oldest families and their love of art and intellectual liberality (Zweig 2000: I40); the fact that, rather than sport and pol-

a completely different view of his work (Raízes do Brazil), clarifying that what he meant by «cordialidade» was a predominance of passion over reason in the Brazilian character that often led to violence and a complicated relationship between the individual and the State. Provided that Zweig had indeed read the work, this could be one more instance of Zweig's utopic thinking, thus favoring optimistic and idealistic interpretations. For a full discussion of the polemic reception of Raízes do Brasil, see, among others, Avelino (1990); De Souza (2007); Costa (2014). 
itics, «intellectual and artistic production is the focus of interest for the entire nation» (Zweig 2000: I42); the reverence for intellectual accomplishments and the eagerness to embrace new ideas notwithstanding tradition; and the prestige of the poet and the intellectual (Zweig 2000: I43), especially as compared to the demise of this figure in the old continent after the First World War (Benda 2008). What is more, when we get to the description of Rio, and especially the subsection «The art of contrasts», we observe a striking resemblance between the Vienna of Zweig's memoirs and the Rio of Brazil, in their idealism, utopianism, and romantic outpouring that even embellishes extreme poverty and illness. To illustrate this point and as a way of closing my analysis of Brazil from the perspective of Zweig's ethical commitment, I offer two lengthy quotes that reveal the process of projection and emotional transference discussed in this article, as well as the shifting process of relocation of Zweig's European utopia:

The more layers a city has, and the more colorful the scale of its contrasts is, the more attractive it will be: that is how it is with Rio de Janeiro. Here the ends deviate from one another in the extreme and yet merge into each other with a special harmony. Wealth does not have a provocative effect here. [...]

Nothing strives against anything else, and in either place, at the bootmaker's shop or in the presence of the aristocrat, you find the same courtesy that agreeably combines all classes together. Those who in other places are separated by enmity or distrust mix freely together here. [...]

You have seen the utmost in primitiveness, the lowest form of housing and life [the favelas], one that you would hardly have thought possible anymore in Europe or North America.

But peculiarly, there is nothing oppressive, nothing repulsive, nothing irritating, nothing shameful about the scene. For these people are a thousand times happier than our proletariat in its tenement houses. It is their own house. (Zweig 2000: 175-178)

[In Vienna at the turn of the century] people believed in «progress» more than in the Bible, and its gospel message seemed incontestably proven by the new miracles of science and technology that were revealed daily. [...] The comfort of upper-class dwellings now reached the homes of the middle classes; water no longer had to be drawn from wells or waterways; fires no longer had to be laboriously kindled in the hearth; hygiene was widespread, dirt was disappearing. People were becoming more attractive, stronger, healthier, and now that there sporting activities to help them keep physically fit, cripples, goitres and mutilations were seen 
in the streets less and less frequenthy. [...] Social welfare was also proceeding apace; from year to year more rights were granted to the individual. [...] They honestly thought that divergences between nations and religious faiths would gradually flow into a sense of common humanity, so that peace and security, the greatest of goods, would come to all mankind. (Zweig 2009: 25-26)

\section{BRIDGING THE GAP BETWEEN UTOPIA AND REALITY}

The publication of Brazil. A Land of the Future was met with great enthusiasm by the reading public. However, many «authorized» voices were not so happy about it, articulating severe criticisms which argued, among other things, that Zweig's look at the country was superficial, lacked historical accuracy, was the byproduct of a persecuted Jew who desperately projected his dream of a harmonious society, was too soft on the policies of the Vargas government, and celebrated an image of Brazil based on leisure and the exotic instead of economic progress and modernization (Dines 198I). For some, Zweig was too conservative; for others, too progressive. Those who read the title — which was subject to controversy — as an affirmation of Brazil's future potentialities ( $A$ A Land of the Future») thought that it was too severe with the present, whereas those who read the text as a celebration of Brazilian society («The Land of the Future»), considered that it was too obliging and uncritical with the difficult situation of the country, which suffered from extreme poverty, political oppression, etc. In this sense, one thing all these criticisms agree on is the fact that there was a huge gap between the utopian and idealistic assessments of Zweig and what was perceived as the Brazilian reality. Although some of these issues may be a matter of opinion and perspective, other omissions are very difficult to justify. For instance, the migration policies regarding Jews, something which directly affected Zweig and his family. In this sense, Matthew Goodwin (2008) argues that, during the thirties, and as the war was getting closer, the Brazilian borders were more difficult to cross for people of Semitic origin. In fact, only after international pressure did Vargas allow the entry of prominent Jews such as Zweig.

How could he turn a blind eye to all this? Was he aware of it but chose not to confront the country that was giving him and his wife a passport and a place to live? Was Brazil, as some claimed, propaganda for the Vargas govern- 
ment? This article has provided some answers to these questions. It is often the case with Stefan Zweig that, the highlighting of the deficiencies and shortcomings of his works are rarely followed by an attempt to understand them. In this case, both the criticisms that point to Zweig's idealism and claims that his text was a way for him to gain the favor of Vargas speak, on the one hand, of the difficult situation the Austrian writer was going through at the time, but also, on the other hand, of his commitment as a writer, his ethical stance and the extent of his utopian thinking. Hopefully, this article has proved that, read from this perspective, Brazil. A Land of the Future acquires another dimension, one in which we can pose our own questions, a (textual) space that did not die with Zweig and which is of paramount importance to understand his legacy and voice as a European, pacifist, humanist, and cosmopolitan writer.

\section{WORKS CITED}

Andrés, Rodrigo (2018). «José Heredia Maya, teórico de la mirada y del rol de la literatura». Rodrigo Andrés; Joana Masó (ed.), Re/visiones gitanas: Políticas, (auto)representaciones y activismos en diálogo con el género y la sexualidad. Barcelona: Edicions Bellaterra, III-I26.

Arendt, Hannah (2004). La tradición oculta. Barcelona: Paidós.

Avelino Filho, George (1990). «Cordialidade e civilidade em Raízes do Brasil». Revista Brasileira de Ciências Sociais, 5 (I2), 5-I4.

Benda, Julien (2008). La traición de los intelectuales. Barcelona: Galaxia Guternberg. Boym, Svetlana (2001). The Future of Nostalgia. New York: Basic Books.

Costa, Sérgio (2014). «O Brasil de Sérgio Buarque de Holanda». Sociedade e Estado, $29(3), 823-839$.

Dewulf, Jeroen (20I4). «Neue Perspektiven zu Stefan Zweigs Brasilien. Ein Land der Zukunft». Klemens Renoldner (ed.), Stefan Zweig: Abschied von Europa. Wien: Christian Brandstätter, I37-I46.

Dines, Alberto (1981). Morte no paraíso: A tragédia de Stefan Zweig. Rio de Janeiro: Nova Fronteira.

Evelein, Johannes F. (20I4). Literary Exiles from Nazi Germany: Exemplarity and the Search for Meaning. Suffolk: Boydell \& Brewer.

Goodwin, Matthew (2008). «The Brazilian Exile of Vilém Flusser and Stefan Zweig». Flusser Studies, I-9.

Hu, Wei (2006). Auf der Suche nach der verlorenen Welt. Die kulturelle und die poetische Konstruktion autobiographischer Texte im Exil; am Beispiel von Stefan Zweig, Heinrich Mann und Alfred Döblin. Berlin: Peter Lang. 
Jounaud, Etienne (2009). «Erasme, ou les ambiguïtés de l'engagement européen de Stefan Zweig» . ¿Interrogations?, 9. [online] [January 23, 2019] <www.revue-interrogations.org/Erasme-ou-les-ambiguites-de-l>.

Kestlen, Izabela Furtado (1992). Die Exilliteratur und das Exil der deutschsprachigen Schriftsteller und Publizisten in Brasilien. Frankfurt am Main: Lang.

LevitAs, Ruth (2013). Utopia as Method: The Imaginary Reconstitution of Society. New York: Springer.

Marquis, Alice Goldfarb (1978). «Jung Wien: Growing Up in the World of Yesterday». Biography I (2), 2I-36.

Matuscheк, Oliver (2011). Three Lives. A Biography of Stefan Zweig. London: Pushkin Press.

Michels, Volker (20I2). «Introducción: Diversidad étnica frente a simpleza racista. A propósito de la génesis del libro sobre el Brasil de Stefan Zweig». Stefan Zweig, Brasil: País de futuro. Madrid: Capitán Swing Libros, II-24.

NitschaK, Horst (2014). «Gilberto Freyre y Sérgio Buarque de Holanda: Mestiçagem y Cordialidade como estrategias de convivencia». Revista Chilena de Literatura, 88, 173-198.

Роотн, Xenia (2005). Der Blick auf das Fremde. Stefan Zweigs Brasilien. Ein Land der Zukunft. Marburg: Tectum Verlag.

Prater, Donald (1972). European of Yesterday. A Biography of Stefan Zweig. Oxford: Oxford University Press.

Prochniк, George (2014). The Impossible Exile. Stefan Zweig at the End of the World. London: Other Press.

Schreiber, George (1936). Portraits and Self-Portraits. Boston: Houghton Mifflin Company.

Schwamborn, Ingrid (1999). Die Letzte Partie. Stefan Zweigs Leben und Werk in Brasilien. Bielefeld: Aisthesis.

Souza, Ricardo Luiz de. (2007). «As Raízes e o Futuro do "Homem Cordial" Segundo Sérgio Buarque de Holanda». Caderno CRH, 20 (50), 342-353.

Stone, Will (20II). «Introduction». Stefan Zweig, Journeys. London: Modern Voices, VII-XVI.

Weidong, Ren (2015). «Das imaginäre Brasilien als Proketionsfläche von Zweigs Europa-Träumen-Stefan Zweigs Brasilien, ein Land der Zukunf». Zhang Yi; Mark H. Gelber (eds.), Aktuälitat und Beliebtheit. Neue Forschung und Rezeption von Stefan Zweig im internationalen Blickwinkel. Würzburg: Königshausen \& Neumann, 229-236.

ZweIG, Friderike (2008 [1964]). Destellos de vida: Memorias [Spiegelungen des Lebens]. Trans. Pablo Álvarez. Barcelona: Papel de Liar.

ZweIg, Stefan (1979 [1934]). Erasmus and The Right to Heresy. Trans. Eden and Cedar Paul. London: Souvenir Press. 
Zweig, Stefan (2000 [194I]). Brazil: A Land of the Future. Trans. Lowell A. Bangerter. London: Ariadne Press.

Zweig, Stefan (2009 [1942]). The World of Yesterday. Trans. Anthea Bell. London: Pushkin Press.

ZweIg, Stefan (20I0). Journeys. Trans. Will Stone. London: Hesperus.

Zweig, Stefan (20I5 [1960]). Montaigne [Kindle]. Trans. Will Stone. London: Pushkin Press.

Zweig, Stefan (20I6 [19I4-I94I]). Messages from a Lost World. Europe on the Brink. Trans. Will Stone. London: Pushkin Press. 